\title{
Analysing the New Millennium Role and Place of Socio-economic Geography in Deepening Regional Economic Cooperation and Integration: The Case of South Africa and Zimbabwe
}

\author{
Godfrey Chikowore ${ }^{1,2, *}$, Harold J. Annegarn ${ }^{3}$ \\ ${ }^{1}$ College of Economic and Management Sciences, University of South Africa, South Africa \\ ${ }^{2}$ Centre for Applied Social Sciences, University of Zimbabwe, Zimbabwe \\ ${ }^{3}$ Department of Geography Environmental Management and Energy Studies, University of Johannesburg, South Africa
}

Copyright $\bigcirc 2018$ by authors, all rights reserved. Authors agree that this article remains permanently open access under the terms of the Creative Commons Attribution License 4.0 International License

\begin{abstract}
Proportional territorial distribution of productive forces historically determined the emergence of socio-economic geography. Deepening regional integration under scrutiny of socio-economic geography culminated in a system of economic regions. These economic regions were further used as special instruments on functional optimisation and management of productive forces guided by specialisation of labor. The process was influenced by scientific and technological advancements, which led to change from a single-sided to an integral multi-factor approach. In these circumstances socio-economic cultural regions emerged as functionally specialised territorial units presenting optimum combinations of productive and non-productive industrial sectors and enterprises. Within this context, the study analyses the role of socio-economic geography in better informing regional integration with reference to South Africa and Zimbabwe. New conceptual terms, such as socio-economic cultural disparities and territorial socio-economic cultural inequalities are proposed. Informed by transformation development theory, the study employs comparative methods of quantitative and qualitative data analysis. It analyses five aspects: (i) application of socio-economic geography to questions of regional integration; (ii) territorial differentiation, factors, forces and relations; (iii) Benefits of economic cooperation and integration for South Africa and Zimbabwe with global economy; (iv) essence of North-South and South-South dialogue; and (v) prospects of the role of socio-economic geography. The conclusions emphasise the role of socio-economic geography, using the newly defined concepts, in articulating a comprehensive theoretical and practical understanding of the processes needed to enhance regional integration.
\end{abstract}

Keywords Socio-economic Cultural Disparities, Socio-economic Cultural Backwardness, Territorial Socio-economic Cultural Inequalities, Socio-economic Cultural Regions, Production Forces and Factors, Regional Integration, Progressive Transformation; Socioeconomic Cultural Value

\section{Introduction}

Under continually changing demands, challenges and conditions of existence of communities, social and economic geography emerged as a scientific discipline to systematically address these circumstances. Definition of socio-economic geography as a scientific discipline was founded in its object [2]; aspect; aim and method of research which in their totality constitute its subject of research. Hence within this conception socio-economic geography constitutes itself as a complex of scientific disciplines which study the objective laws governing the distribution of production in society (understood as the integral relationship of productive forces and relations) and settlement of the population (in other words territorial organization of human life in society and the specific forms in which in manifests in different countries; regions; and places), [2]. Sophistication of the integral relationship of productive forces and relations and rationalization of territorial organization of human life in society and the manner in which it manifests different countries; regions and places has occurred in great proportions as to warrant the examination of the role and place of socio-economic geography in the new millennium. In the light of these changing circumstances this study seeks to analyse the 
new millennium role and place of socio-economic geography in conditions of deepening regional economic cooperation and integration in Southern Africa within special attention to the Republic of South Africa and Zimbabwe over the transitional period from colonialism to independence. The evolutionary processes under influence of science and technology and deepening of regional integration have found extensive theoretical and practical application and definition in the historic scientific contributions by Alaev E B [2] entitled "Socio- economic geography: conceptual terminological dictionary"; the illustrious progressive contributions on transformation in the new millennium by Frederick P Stutz and Barney Warf [9] entitled "The world economy: geography, business, development, $6^{\text {th }}$ edition"; the key progressive development contribution by Nafziger E Wayne [12] entitled " Economic development, $4^{\text {th }}$ edition " and many other key contributions to development and transformation in general and in particular to sub Saharan Africa, South Africa and Zimbabwe. Making comparisons on a historical parallel, the study analyses the manifestation of organization and management of productive forces and relations and the settlement patterns in both the rural and urban areas. These processes are analysed relative the influence of objective factors governing spatial population settlements and distribution of production forces and relations. Key reference on the theory and practice of regional economic integration and cooperation in South Africa and Zimbabwe are consulted notably the 2000-2006 Official SADC Trade, Industry and Investment Review series; the 2000-2015 Southern African Development Community: Regional Indicative Strategic Development Plan; Andre Roux [1] Everyone's guide to the South African Economy, $10^{\text {th }}$ edition; the 1988 - 1997 World Development Report series and many other illustrious contributions. Illustrative maps of South Africa and Zimbabwe in both text and references are extensively employed to explain and expose the essence of the processes under scrutiny in conditions of regional integration. Specific terms and conceptual phrases to this discussion are herein developed as cited in the keywords section, namely "socio-economic cultural disparities" implying the uneven growth and development of material and spiritual values and wealth across continents, regions, countries and places. Equally key terms as "territorial socio-economic cultural inequalities" implying the unequal levels, rates of growth and development of productive forces and relations as a historical function are herein examined in their spatial context. The study adopts these concepts by addressing four key questions. These are namely the essence of the role and place of socioeconomic geography and deepening regional economic integration and cooperation; the essence of territorial distribution of production forces, progressive and retrogressive factors and outcomes; the role of North South and South - South Development Dialogue as a regional integration catalytic variable; and prospects, hurdles and alternatives to the role of socio-economic geography in deepening economic integration. The study finally proposes new terminological phrases to socio-economic geography without which the theoretical and practical understanding of the process of regional integration as a vehicle for transformation would be difficult. These terms emerge as new tools for socio-economic geography in that they extend the theoretical boundaries which at the same time give more elaborate insights into the phenomenon under scrutiny than if they were not proposed earlier on. Last but not least the conclusion notes that the newly proposed terms modify the theory of socio-economic geography so that they could best apply to regional economic integration as an adopted strategy for transformation.

\section{Literature Review}

An extensive reference is made to primary and secondary materials available in the library. These are considerably complemented by materials from development studies realms and data sheets with key socio-economic cultural variables. These variables present a historical trend of the influence socio-economic geography had in shaping the process of regional economic cooperation in South Africa and Zimbabwe. Mainly the reference materials are within the realm of the theory of development transformation and the political economy of development of nations and communities worldwide. The conceptual book by Alaev E B [2] entitled "Social and economic geography: conceptual and terminological dictionary " provided terms that are specific to socio-economic geography in making regional economic cooperation better understood as a strategy for progressive transformation in developing countries and in particular South Africa and Zimbabwe. Providing critical and factual information on prospects of socio-economic cultural development in the SADC and in particular opportunities and challenges faced by each member state are the "2002- 2006 Official SADC trade, industry and investment review series", [14], [15] and [16]. These series are potentially crucial to the extent that they provide illustrative maps depicting the territorial socio-economic cultural development disparities in both South Africa and Zimbabwe. These contributions inform the prospective donors and development partners within the region, sub Saharan Africa and the greater world about the prevailing investment possibilities in Southern Africa. Defining the development challenges from an economic perspective and conceptually complementing the role of socio-economic geography in giving better form to the process of regional economic integration in Southern Africa is the Nafziger E Wayne [12] publication entitled "Economic development, $4^{\text {th }}$ series". The contribution 
expands on the strategies that inform and modify the theory and practice of socio-economic geography in order that it finds application in regional economic cooperation as nation transform progressively. Giving a critical analysis to prerequisites for regional integration to take form in Southern Africa and the prospects as well as challenges it faces in Africa as a whole are the key theoretical contributions by the African Development Bank [15] entitled "Economic integration in Southern Africa, Volume 1 and 2 and the Sipho Buthelezi contribution entitled Regional Integration in Africa: prospects and challenges for the $21^{\text {st }}$ century, Volume 1", [5]. On a development note these contributions on one hand inform socio-economic geography about the strengths and weaknesses of regional integration as a basic principle for transformation. On the other hand conceptual modifications to the theory and practice of socio-economic geography so that it renders better understanding and more meaning to processes of regional economic integration are created. Socio-economic cultural processes functionality outcomes are discussed in a macroeconomic oriented analysis edited by Chinyamata Chipeta and Klaus Schade [8] series entitled "Deepening integration in SADC: Macroeconomic policies and social impact- A comparative analysis of 10 Country studies and surveys of business and non- state actors". Illustrious debates centred on mal-bureaucratic practices which grossly compromised development oriented modifications of the theory and practice of socio-economic geography in enhancing regional integration processes as a vehicle for socio-economic cultural transformation were pursued in an illustrated edition by Stephen Weir [13] entitled "History's worst decisions and the people who made them". A critical development oriented edited contribution by Alioune Sall [3] in a book entitled "The future competitiveness of African economies" debated three approaches. These were namely the passive, reactive and forward - looking approach which anticipates events in order to influence them. Certainly the first two approaches would not complement the role of socio-economic geography in enhancing processes of regional integration. By all reasonable logic the last third approach would lead to conceptual modifications with a meaning for better informing the process of regional integration. Complementing the regional integration enhancing role of socio-economic geography is the landmark contribution by Andre Roux [1] entitled "Everyone's guide to the South African economy, $10^{\text {th }}$ edition". This work investigates the causes and consequences of the 2008/2009 global financial crisis, with more emphasis on the sub Saharan Africa economy, while further exploring human development issues in South Africa and their implications for foreign policy. Quite informative and adding conceptual development and modifications to the theory and practice of socio-economic geography in enhancing regional economic integration is the SAPES-UNDP-SADC [14] co-authored contribution entitled "SADC regional human development report". This book investigates the challenges and opportunities for regional integration which approach orientates socio-economic geography to ranks of adaptation and innovation as means to rationalize regional economic integration get formulated in the long term. Reflecting the character of management of production forces and relations and human settlement patterns in regions of the world are the 2007-2009 World Population Data sheet series [20]. Defining economic geography and pursuing a debate on spatial disparities across the world is the contribution by Frederick P Stutz and Barney Warf [9] entitled "The world economy: geography, business, development, $6^{\text {th }}$ edition". Last but not least the key contributions by "United Nations, DPI [18] Basic Facts about the United Nations"; and the "2000-2015 Southern African Development Community: Regional Indicative Strategic Development Plan" show the development potential inherent in the North - North and South - South Development Dialogue Programmes [14]. These generate modifications in the theory and practice of socio-economic geography relative the aspect of factors influencing the processes of regional economic integration.

In concluding the literature review it is essential to note that conceptual modifications in the theory and practice of socio-economic geography inherently better inform the process of regional economic integration which in turn leads to faster socio-economic cultural growth and development of nation states.

\section{Methodology}

Essentially the reality of examining South Africa and Zimbabwe presupposes the use of comparative methods in qualification of the territorial socio-economic cultural development inequalities within and between the two nation states. Descriptive quantitative and qualitative data analysis methods are also used to qualify the functional character of productive forces and relations combined. Illustrative geographical physical, political and economic maps depicting territorial socio-economic cultural development disparities and regions of Zimbabwe and South Africa make a clear exposition of the challenges facing socio-economic geography in enhancing regional economic integration. Theoretical analysis of secondary and primary data from the libraries is quite central to this research as confirmed in part by the key contributions examined under the literature review.

\section{Discussion}

- Application of the role and place of social and economic geography and enhancing regional economic integration and cooperation.

As defined in the introductory, the role and place of 
socio-economic geography in enhancing the process of regional economic integration constitutes studying the laws on distribution of production in society, (alternatively meaning the integral connection of productive forces and relations) and human settlement, (meaning territorial organization of human life in society and the specifics of its manifestation in different countries, regions and places). According to the illustrative factual data presented in the [14].,[15].,[16] Official SADC Trade, Industry and Investment Review the physical and political variables indicate a six-level height above sea -level for South Africa $(0-200 ; 200-500 ; 500-1000 ; 1000-2000$; over 3000 meters), [16]. South Africa mountain peak on the Drakensberg is calibrated 2770 meters while as it stretches into Lesotho the Drakensberg mountain second peak calibrates higher at 3482 meters above sea level. With regards to Zimbabwe the calibration is lower with a five-level height above sea-level, namely 0-200; 200-500; 500-1000; 1000-2000; over 2000 meters. Zimbabwe Inyangani mountain peak measures 2592 meters above sea level. Naturally the climatic conditions on a comparative parameter are more favourable over the South Africa territory by virtue of the wider calibration $0-3000+$ meters above sea level which is in excess of Zimbabwe by $1000+$ meters above sea level, [15]. Apart from the climatic conditions the six and five level physical calibration of the two nations present them with comparatively considerable potential for tourism industry. This potential is higher for South Africa by virtue of the $1000+$ meters advantage it has over Zimbabwe.

As alluded in the above height above sea-level argument, the socio-economic cultural inequalities and territorial socio-economic cultural inequalities can get either more pronounced or less pronounced and get reduced to the least minimum depending on the level of management of productive forces and organization of productive relations.

Of great socio-economic cultural significance relative the physical calibration is agriculture and agricultural specialization in each level for instance in the $0-200 \mathrm{~m}$ above sea -level it is in both cases deemed agriculturally unproductive land on one hand. Nevertheless, the process of transformative regional integration under the influence of science and technology has the potential to economically activate these regions. On the other hand on the other extreme $2000+$ meters above sea-level it is in both cases deemed regions of high economic potential because of the agricultural and industrial potential generated by the calibration. In these regions tea; coffee; sheep; goats and wheat are cultivated. The rest of the crops and animal breeding fall within the 200-2000 meter above sea-level calibration range. In terms of the physical calibration the resources endowment of the South Africa and Zimbabwe broadly qualify into 4-5 main regions. These are namely forest; cash crop; food crops; national park and game reserve; and unproductive land with varying degrees of territorial coverage, see table 1 below.
Forest coverage enjoyed by both South Africa and Zimbabwe at 4 and $3.5 \%$ respectively ensures of greater underground water resources; reduction of desertification processes; greater and stable fauna and flora species; aesthetic-scenic landscape, see table 1. As regards the cash crop category, territorial coverage for South Africa and Zimbabwe is 73 and $67 \%$ respectively indicating a greater potential for the former. This points to a higher and diversified agro-industrial base in South Africa with a precedent for development of agro-industrial complexes in Zimbabwe in the medium and long term. A larger portion of the cash -crops constitute raw material for the value addition small - medium enterprises. The combination of urban centres ranging from the capital cities; important towns and other towns should in the medium and long term evolve to industrial centres evenly distributed on the territories on two nations under scrutiny. Food crops which for South Africa and Zimbabwe constitute a territorial coverage of 20 and $18 \%$ assures of a reliable raw material base for an already established and newly emerging agro-industrial complex. Challenges on elimination of socio-economic cultural disparities become a key concern in the revival and location of new industrial complexes through rural and urban areas as the process of regional integration advances. Socio-economic cultural disparities refers to the unequal distribution of living conditions which emanates from retarded processes of creation of material and spiritual wealth by communities in specific locations as nation states, regions and continents of the world. In circumstances of existing capital cities; important towns and other towns, socio-economic cultural inequalities may intensify if there is an improper planning of productive forces within and between urban and rural areas. In circumstances where these inequalities occur spatially, the outcome becomes territorial socio-economic cultural inequalities. Of great importance is the area covered by national and game parks in South Africa and Zimbabwe measuring 2.8 and $5 \%$ respectively see table 1 . The socio-economic cultural significance of these indications is that South Africa and Zimbabwe have a reserve of rare fauna and flora species in their natural state which are being threatened by extinction on one hand. On the other hand the national and game parks present themselves as tourist attractions of own kind and generate revenue in that respect as tourists get to these destinations. In 1990 and 2001, inbound tourists for South Africa were 1,029 and 5,908 mln and while outbound tourists were 0,616 and 3,363 mln. For the same period international tourism receipts were 992 and 2,707 US\$ mln comprising 1.7 and $2.7 \%$ of the exports, [17]. With respect to Zimbabwe inbound international tourists over the 1990 and 2001 period were $0.605 \mathrm{mln}$ and $1,868 \mathrm{mln}$ respectively while outbound were 200 and 331 respectively. Equally, Zimbabwe international tourism receipts for 1990 and 2001 were 60 and 125 US\$ mln which comprised 3.0 and $5.9 \%$ of the total exports, [17]. 
Table 1. Comparative socio-economic cultural land use pattern in South Africa and Zimbabwe, \%

\begin{tabular}{|c|c|c|c|}
\hline Category & South Africa & Zimbabwe & Dominating activity / culture \\
\hline Forest & 4 & 3.5 & Wildlife \\
\hline Cash - crop & 73 & 67 & $\begin{array}{c}\text { Cotton; tobacco; cattle; citrus fruit; tea; coffee; sugar cane; groundnuts. } \\
\text { Cattle* sheep*wheat*sorghum*maize* }\end{array}$ \\
\hline Food -crop & 20 & 18 & $\begin{array}{c}\text { Cattle; goats; sheep } \\
\text { Maize*; sorghum*; citrus fruit*; sugar -cane* }\end{array}$ \\
\hline $\begin{array}{c}\text { National park / Game } \\
\text { reserve }\end{array}$ & 2.8 & 5 & Preserved (large - small )fauna and flora species threatened by extinction: \\
\hline Unproductive land & 0 & 6 & High reclamation potential. \\
\hline Total \% & $\mathbf{9 9 . 8}$ & $\mathbf{9 9 . 5}$ & Key: * refers to South Africa. \\
\hline \multicolumn{2}{|c|}{} \\
\hline
\end{tabular}

Source: [14],[15] and [16].

What is qualified as unproductive land appears to be only in Zimbabwe and not in South Africa. The paradox of this phenomenon is that while unproductive land could lead to socio-economic cultural backwardness of localities, nations, regions and continents on one hand it can on the other hand through reclamation be a condition for progressive transformation. Socio-economic cultural backwardness, [9] refers to a less progressive way of living which derives from retarded processes of material and spiritual wealth creation by communities in specific locations as nation states, regions and continents of the world, [6]. The 0 and $6 \%$ score for South Africa and Zimbabwe for the unproductive land variable may in the long run create a competitive socio-economic cultural advantage over South Africa through a proper planning of development of productive forces within a medium or long term territorial reclamation program.

With respect to height above sea - level for South Africa and Zimbabwe, the territorial 5 - 6 level calibration $(<200-3000>$ meters above sea- level) has significance in terms of the rational planning and development of productive forces and optimum exploitation of productive factors. Productive forces are a combination of objects; instruments and subjects of labour while production factors are just the moving forces of a given process, especially social, economic, and political or a combination of two or all the outlined variables. Table 2 actually indicates a general outline of socio-economic cultural activities that characterize the 5-6 levels of height above sea - level. Normally for sea - bounded nation states, the 0-200 meters are potentially high productive agricultural zones, with fishing industry dominating. Mineral deposits as salt, diamonds; and phosphates are actually predominant. As regards continentally located nation states, these zones are mainly unproductive land which had to be reclaimed through amelioration reclamation programmes. Transformation prospects for sea- bordering nations in terms of industrialization would be limited to environmental prescribed guidelines as nature conservation and preservation would be a priority. As for the continentally located the $0-200 \mathrm{~m}$ level would generally be arid and hot. Mostly sugar-cane; wheat, national and game parks would be main economic activities. Industrialization would be mainly in the line of land amelioration and irrigation as a reclamation programmes on economically activating the zones. Over the 200-500 meter sea-level there normally a combination of cash and food crops mainly with the domination of the cash crops as agro-climatic conditions get more favourable, see table 2. For South Africa it is normally sugar - cane and wheat and sheep raring, while for Zimbabwe sugar - cane and ground nuts as cash crops over the food crops. Over the 500- 1000 and 1000-2000 meters above sea-level cash agricultural crops, sheep and cattle breeding dominate over food crops in a wider variety. As for above 2000 meters range, potential for tourism increases while cash crops and animal breeding gets more specialized. Cash crops include mostly tea, coffee; citrus fruits. In this respect all important towns; other towns; growth points and other development nodes have to be economically activated through small medium enterprise programmes on value addition to agricultural raw - materials specific to those zones. These towns, points and nodes would certainly have to evolve into more superior industrial centres with time and not remain static or degenerate into ghost locations because of either death or absence of enterprises due to poor short, medium and long term planning. As such table 2, enables optimization of organization of socio-economic cultural processes in planning of national development. 
Analysing the New Millennium Role and Place of Socio-economic Geography in Deepening Regional Economic Cooperation and Integration: The Case of South Africa and Zimbabwe

Table 2. Relationship of physical calibration and territorial socio-economic cultural development in South Africa and Zimbabwe

\begin{tabular}{|c|c|c|c|c|c|}
\hline \multirow{2}{*}{$\begin{array}{c}\text { Physical } \\
\text { calibration; } \\
\text { meters. (above sea } \\
\text { level). }\end{array}$} & \multicolumn{2}{|c|}{ South Africa } & \multicolumn{2}{|c|}{ Zimbabwe } & \multirow[t]{2}{*}{$\begin{array}{l}\text { Transformation } \\
\text { prospects }\end{array}$} \\
\hline & agriculture & industry & agriculture & industry & \\
\hline \multicolumn{6}{|l|}{$3000+$} \\
\hline $2000-3000$ & Sheep; maize; sorghum & & & tea & $\begin{array}{l}\text { High - natural } \\
\text { scenic resources; } \\
\text { development with a } \\
\text { tourist bias. }\end{array}$ \\
\hline $1000-2000$ & As below; citrus fruit & $\begin{array}{l}\text { Few industrial centres; } \\
\text { other towns dominate; } \\
\text { gold; chrome; silver coal; } \\
\text { uranium; asbestos. }\end{array}$ & $\begin{array}{l}\text { Cotton; tobacco; sheep; } \\
\text { cattle; cash crop } \\
\text { dominate over food } \\
\text { crop; citrus fruit }\end{array}$ & $\begin{array}{l}\text { International airport; } \\
\text { sparse industrial } \\
\text { centres; gold*; nickel; } \\
\text { copper; iron ore; } \\
\text { national and game } \\
\text { parks }\end{array}$ & $\begin{array}{l}\text { Considerably high } \\
\text { along lines of } \\
\text { small-medium scale } \\
\text { enterprise based } \\
\text { industrialization in } \\
\text { rural and urban } \\
\text { settlements }\end{array}$ \\
\hline $500-1000$ & $\begin{array}{c}\text { Mainly cash crop } \\
\text { dominate; deciduous } \\
\text { fruit; cattle; sheep } \\
\text { dominate*; sparse parks }\end{array}$ & $\begin{array}{l}\text { Coal; chrome; important } \\
\text { towns *; other towns; } \\
\text { capital city; lead and zinc }\end{array}$ & $\begin{array}{c}\text { Tea; coffee; } \\
\text { Cattle and cash crop }\end{array}$ & Sparse other towns. & $\begin{array}{l}\text { Developing other } \\
\text { sparse towns into } \\
\text { industrial centres. }\end{array}$ \\
\hline $200-500$ & $\begin{array}{c}\text { National parks; } \\
\text { cattle;maize; sugar- } \\
\text { cane; wheat; sheep (cash } \\
\text { crop dominate over food } \\
\text { crop); deciduous fruit }\end{array}$ & $\begin{array}{l}\text { Sparse industrial centres; } \\
\text { more other towns; iron } \\
\text { ore; manganese and coal; } \\
\text { copper; tin and gold }\end{array}$ & $\begin{array}{l}\text { Cash dominate food } \\
\text { crop: sugar -cane; tea; } \\
\text { coffee; groundnuts; } \\
\text { cattle; sheep; citrus } \\
\text { fruit; }\end{array}$ & $\begin{array}{l}\text { National and game } \\
\text { parks; gold; chrome; } \\
\text { tin; coal; iron ore }\end{array}$ & $\begin{array}{l}\text { Industrialization } \\
\text { based on value } \\
\text { addition to food } \\
\text { crops }\end{array}$ \\
\hline $0-200$ & $\begin{array}{l}\text { sparse forest; wheat*; } \\
\text { maize, sugar cane* (cash } \\
\text { crop and food crop } \\
\text { combine); more food } \\
\text { crop is grown }\end{array}$ & $\begin{array}{l}\text { Dense coastal industrial } \\
\text { centres; fishing*; salt; } \\
\text { phosphates* on coastal } \\
\text { regions. diamonds*; salt; } \\
\text { international airport }\end{array}$ & None existent & None existent & $\begin{array}{l}\text { Protection of the } \\
\text { environment. } \\
\text { Limited pace for } \\
\text { industrialization } \\
\text { based on existing } \\
\text { complexes. }\end{array}$ \\
\hline
\end{tabular}

Source: [14],[15] and [16].

For purposes of effective political administration and promoting regional integration the Republic of South Africa and Zimbabwe have been subdivided into provinces; states or zones based referred to as socio-economic cultural regions, refer to maps $1 ; 2$ and 3. In other circles they are referred to as economic regions which are specific demarcated territories in whose parameters there is a clear reflection of specialized division of labour based purely on economic variables and principles of performance of enterprises. However in the case of socio-economic cultural region, the conceptual phrase is more embracing and constitutes itself an integral territory demarcated on a principle of specialized functional combination of social, economic, cultural and other related factors. These specialized combinations include the productive; non - productive; creative and services sectors and enterprises meant to improve growth and development of the state; the welfare of the members of the community as carriers of culture and creative potential. The driving factor is no longer economic as for the economic region but human as the driving factor. As reflected in map 1. South Africa has .... Socio- economic cultural regions namely: the Northern Province (Transvaal) with Polokwane (Petersburg) as capital; Gauteng with Johannesburg and Pretoria as twin capitals; Mpumalanga (Eastern Transvaal) with Nelspruit as capital; Kwazulu
Natal with Pietermaritzburg - Durban as shared capitals; North West with Mafikeng and Klerksdorp as shared capital cities; Orange Free State with Bloemfontein as the capital capital; Northern Cape with Kimberley as capital; Western Cape with Cape Town as the capital and Eastern Cape with Bisho and Port Elizaberth as shared capital, see maps 1 and 2. Not all these capital cities are industrial centres. Some are just important towns while others have an "other town status"

Each of these socio-economic cultural regions has regional capital city; a network of important towns; a network of other towns; development nodes and growth points, see maps 1 and 2. Rail and road networks are quite developed and constitute a precedent for faster development of the national economy through speeding up of regional economic integration within and beyond South Africa. Together South Africa has nine socio-economic cultural regions.

Zimbabwe has eight socio-economic cultural regions and these are Mashonaland West with Chinhoyi as capital; Mashonaland Central with Bindura as capital and Mashonaland East with Harare as the capital; Manicaland with Mutare as the capital; Midlands with Gweru as the capital; Masvingo (Victoria) with Masvingo as the capital; Matebeleland North with Bulawayo as capital and Matebeleland South with Gwanda as capital, see map 3. 
Road infrastructure for Zimbabwe is considerably intact though it requires upgrading, there is scope for promotion of regional integration based socio-economic cultural transformation, see map 3. Not all capitals are industrial centres because most enterprises either closed down or relocated to neighbouring nations.

What then are the challenges for socio-economic geography in these circumstances? Industrial centres; capital cities; important towns and other towns should not degenerate but should have diversified industrial combinations of productive, non - productive; creative and service sectors and enterprises. In concluding this sub - question it would be necessary to emphasize that role of socio-economic geography in promotion of regional integration is to ensure that formerly existing capital cities; industrial centres; important towns and other towns evolve to more superior and dynamic enterprise combinations and they should not be allowed to degenerate into ghost locations. This can only be achieved through maximum utilization of the opportunities offered within the North South and South - South Development Dialogue in a context perceived home-grown universally acceptable socio-economic cultural transformative development plans.

\section{Republic of South Africa}

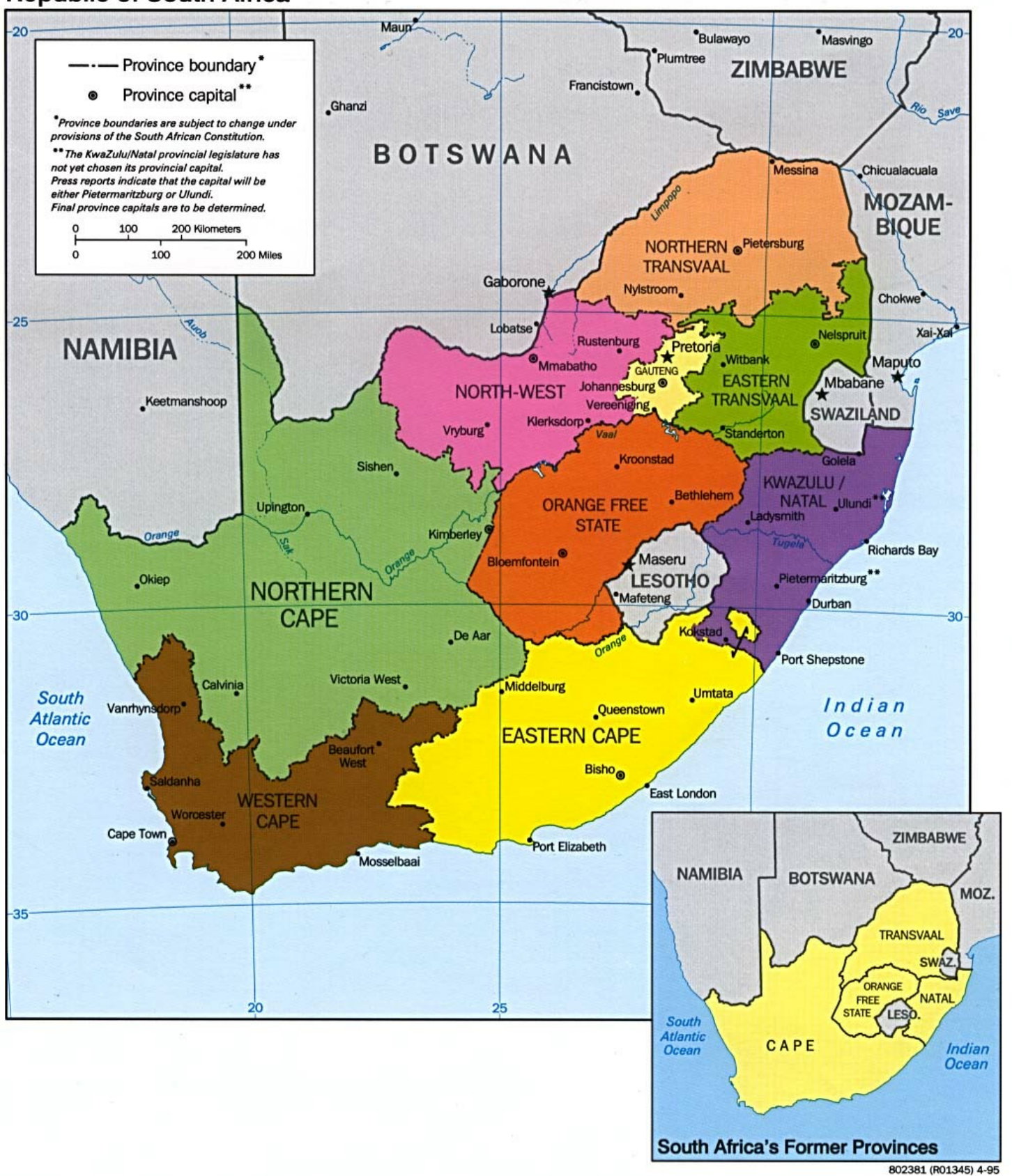

Source: http://images.nationmaster.com/images/motw/africa/safrica provinces 95.jpg.

Map 1. Illustrative socio-economic cultural regions of the Republic of South Africa 

Cooperation and Integration: The Case of South Africa and Zimbabwe

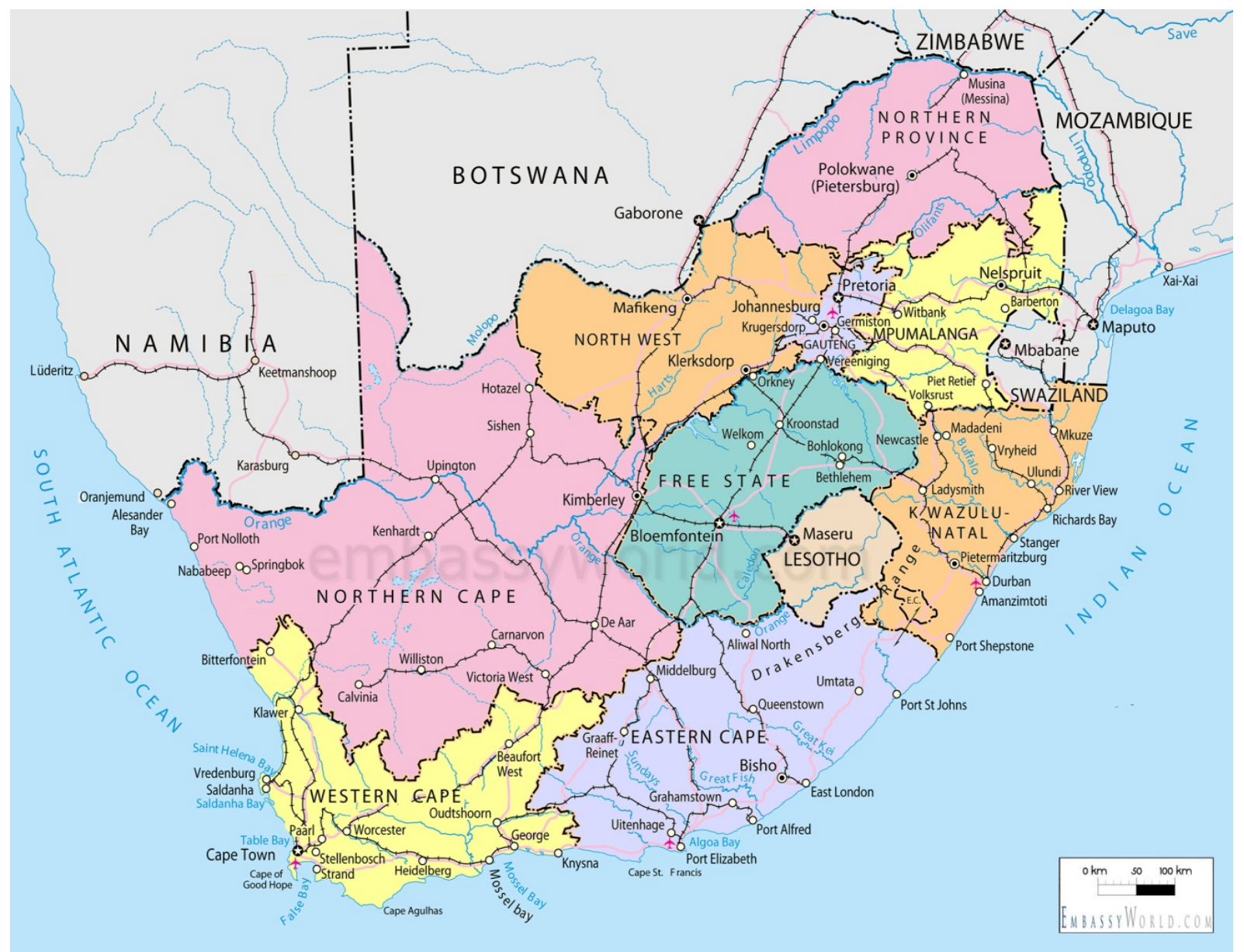

Source: http://images.nationmaster.com/images/motw/africa/safrica provinces 95.jpg

Map 2. Developed system of socio-economic cultural regions of the Republic of South Africa 


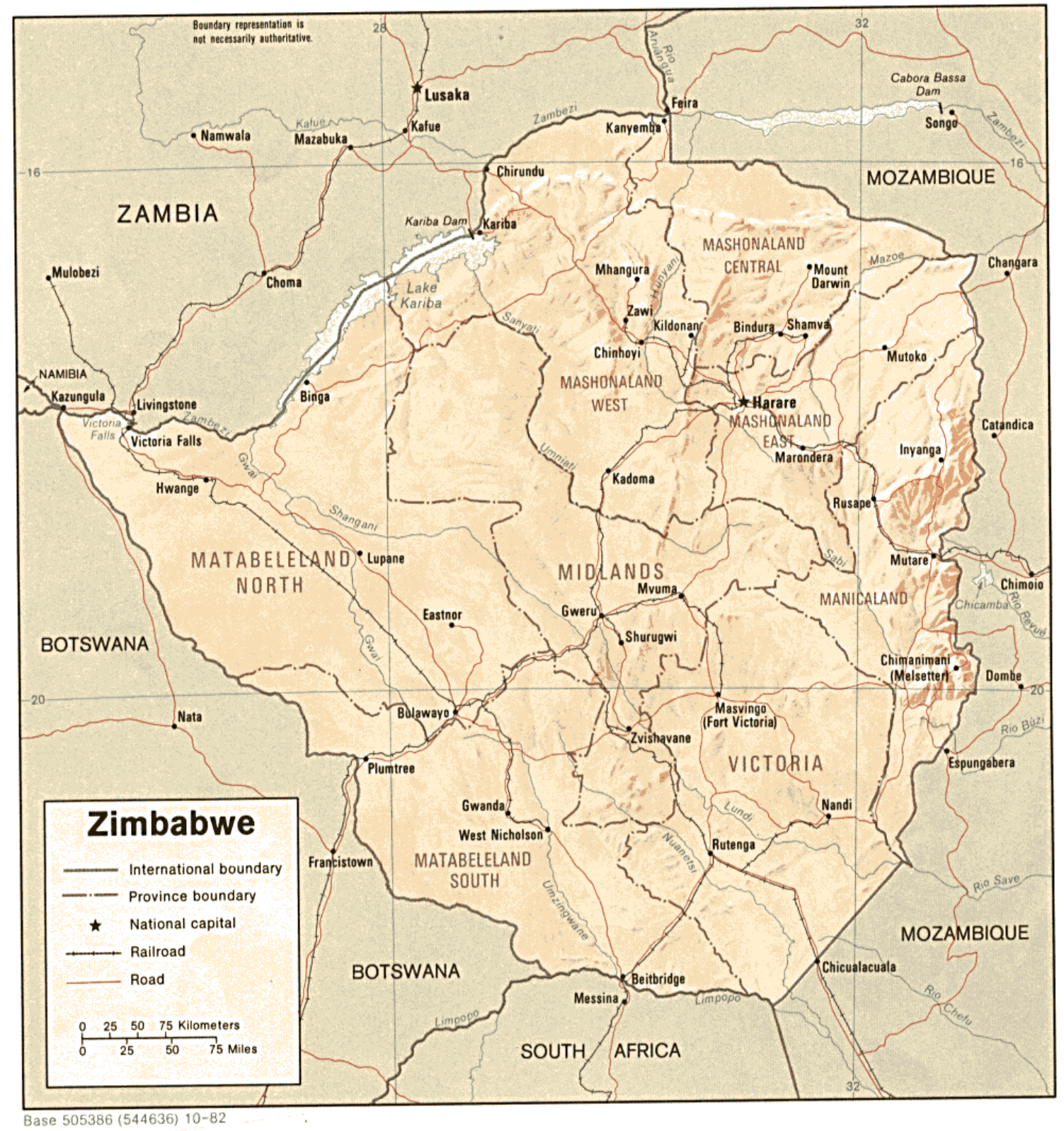

Source: http://images.nationmaster.com/images/motw/africa/zimbabwe.gif.

Map 3. System of socio-economic cultural regions of the Republic of Zimbabwe

- Essence of territorial distribution of production forces; progressive and retrogressive factors and outcomes.

The 1997 World Development Report published categories of socio-economic cultural classification of nation states labelled as High - Middle and Low Income Economies, [19]. Alternatively this was an outcome of the function of productive forces from the colonial period through to the independence era based on an aggregated weighting of key variables. The variables are population; area; per capita Gross National Income (GNP per capita); GNP purchasing power parity (GNP ppp); poverty, percentage of people living on less than 1US\$ per day; life expectancy at birth and adult literacy levels. Even in the contemporary, on the basis of these key variables Zimbabwe was situated in the Low Income Economies category (LIE) in group $8-5$ and on number 38 out of a total of 10 groups of five member nation composition in the low income economies category. South Africa was situated in a more advanced position and category in socio-economic cultural terms as defined by the key variables. South Africa was in the Middle Income Economies category (MIE) which is further subdivided in to the lower middle income and upper middle income sub - categories. Even in the cotemporary South Africa was situated in the Middle Income Category but in upper middle income sub category in group $20-5$ and on number 91 out of a total of 13 groups of five member nation 
composition in the middle income economies groups, [19]. Out of a total of 209 nation states considered by the World Bank in the socio-economic cultural classification three groups emerged. The groups comprised 49 Low Income Economies category member nations; 57 Middle Income Economies category of which 40 are lower middle income while 17 are upper middle income; and 25 High Income Economies member nations (total 133 nations) complemented by 76 other economies deemed smaller and not of scale. What then are the challenges generated by the socio-economic cultural categorization by the World Bank for socio-economic geography in enhancing regional economic cooperation and integration of these nations within and as members of regional economic blocs and as part of the global economy? Certainly for South Africa and Zimbabwe the challenge involves moving up the two member nations in a two dimensional programme. The first programme would involve a movement up the classification numbers from 38 for Zimbabwe and 91 for South Africa towards the maximum of 133 for the wealthiest in the last $28^{\text {th }}$ group of 5 High Income Economies world wealthiest nations (United States; Germany; Denmark; Norway; Japan and Switzerland). In other words in enhancing regional integration and progressive transformation, the role of socio-economic geography would be to move Zimbabwe and South Africa, as fast as possible from the other lower extreme end of the pole comprising the least developed first $1^{\text {st group of } 5}$ Low Income Economies world poorest nations (Mozambique; Ethiopia; Tanzania; Burundi and Malawi ), [19]. The second programme would be for socio-economic geography to move the nation states Zimbabwe and South Africa through the socio-economic classification categories. For Zimbabwe it would imply movement from the Low Income Economies category to the Middle Income Economies category through the lower and upper middle income sub - categories and finally breaking through into the High Income Economies categories on one hand. On the other hand for South Africa it would imply the role of socio-economic geography would be inducement of movement from the Middle Income Economies, upper middle income economies sub category through to the High Income Economies category. How will these programmes be translated into practise? A rational distribution of productive forces and organization of productive relations and population settlement patterns in rural and urban areas has to be adopted as the guiding principle. Progressive transformation has to be observable in the industrial centres; capital cities; important towns; other towns; growth points and development nodes in urban and rural areas, see maps $1-2$ and 3, for South Africa and Zimbabwe. Planning of the distribution of productive forces and development of productive relations and settlement patterns should essentially culminate in the progressive transformation. The transformation should occur through all the above cited socio-economic cultural objects, for instance industrial centres, capital cities, through to development nodes existing with the socio-economic cultural regions of South Africa and Zimbabwe, see maps 1-2 and 3. Calibrated meters above sea-level for both nations should enable a progressive rationalization of the transformation process through optimum combinations of productive forces; management of productive relations and development oriented population settlement pattern. As alluded in the development oriented informative and educative contribution by Frederick P Stutz and Barney Warf [9] entitled "The world economy: geography, business and development. $6^{\text {th }}$ edition" caution needed to be taken in ensuring optimum combination of development factors. Specifically population growth should not be allowed to tax the available resources but should enable more investment to enable a level of higher real capital growth per person. What this means is that if public and private investment fails to keep pace with the population growth, each worker will become less productive, having fewer tools and less equipment with which to produce goods and services. What this implies in other words is that the population becomes starved and stunted in terms of creativity and innovation at a time when creativity and innovation make essential ingredients for regional integration to progress. Further this retrogressive scenario will mean inability to access development opportunities and effective mutual exclusion of the population in South Africa and Zimbabwe from the process of regional economic integration. The process of escalating the two nations would have to ensure that their national economies generate enough jobs to curb unemployment and underemployment. This would be achievable through making agriculture more viable and an income generation sector in the rural areas. Agricultural prices in rural areas would have to be reasonably high, by way of promoting adequate public investment in rural agriculture and speeding up land reform, [9]. Because domestic pools of investment are low and very limited poor countries rely on foreign direct investment given by transnational corporations which can be fickle, in most cases leading to social, economic and environmental costs. Consequently unemployment and underemployment in the two nations would be curbed through promotion of domestic investment and especially its predominance over the investment level of the transnational corporations. Low labour productivity would have to be eliminated through movement to economies of scale by moving from typically small scale farming operations which are normally subsistence based. Arresting low labour productivity would also require investment in human capital such as education; health and other social services which make unskilled into productive workers. The process of transforming the economies of South Africa and Zimbabwe should also promote capital and investment because lack of capital in the form of 
machinery, equipment; factories, public utilities and infrastructure in general contributes to socio-economic cultural backwardness. In other words the relationship between output per worker and per capita investment is closely related to the relationship between investment and income. Sufficient and adequate technologies have to be continually adopted in South Africa and Zimbabwe in order to increase productivity and accumulate wealth. A much faster way of addressing this challenge would be to acquire new production techniques through technology transfer that may accompany investment by transnational corporations as what occurred in the newly industrializing countries of East Asia. There is also need to ensure an equal and equitable distribution of land [13] so that the small minority does not end up controlling the vast bulk of valuable land. In Southern Korea immediately after the Korean War most of the farmable land was given to the majority and this measure allowed for increased agricultural productivity and the development of an industrial and commercial middle class that made South Korea one of the success stories of the Pacific Rim. Trade terms [14] have to be made positive by way of selling relatively high value goods, which are manufactured commodities and imports relatively low valued commodities. This situation evidently generates foreign revenues that allow it to pay off debt or to reinvest revenues in infrastructure, human capital and new technologies. Otherwise poor terms of trade will remain if these countries continually supply minerals and food stuffs, exporting low - valued primary sector goods while in return importing expensive high valued manufactured goods. Equally socio-economic cultural competitiveness will reflect in the reduction of foreign debt [4] to least percentage levels of the Gross National Product in the $10-15 \%$ range would be quite ideal for the country to develop independently. Equally restrictive gender roles have to be reversed such that privileges and obligations for both men and women in all social strata and circles of life are equalized. Equally corrupt and inefficient governments should be continually eliminated in South Africa and Zimbabwe. Bureaucrats whose primary interest is catering for the elite and foreign investors, creating governments that are at best indifferent and often outright hostile to the needs of their own people. Most public policies of less developed countries are ineffectual or counterproductive and typically ignore the rural areas in favour of cities. This in most cases results in public services and the public sector being underfunded and being highly inadequate. All these present alternatives which show that socio-economic geography could avail for the process of regional cooperation to progress and bring transformation to the rural and urban areas of South Africa and Zimbabwe, are alike in the short, medium and long term.

- Benefits of economic cooperation and integration for South Africa and Zimbabwe with global economy.

On a backdrop of integral socioeconomic cultural planning in urban - rural communities the centrality of socioeconomic geography in deepening economic cooperation and integration in Southern Africa especially for the Republic of South Africa and Zimbabwe, is well depicted in Table 3, below. A close examination of the development trends in population growth, net migration rate flows; GNI per Capita US\$; urban percent and infant mortality rate do attest to the levels of hurdles and benefits inherent in economic cooperation and integration for South Africa and Zimbabwe as per the existing data for 2007 and 2016.

Table 3, clearly depicts how the Republic of South Africa with its economic potential within the global economy could well promote socioeconomic development and transformation in Zimbabwe in the short, medium and long term.

While population has increased for Zimbabwe and South Africa over the 2007 and 2016 period, the same increase has been experienced, globally, in Africa, least developed regions; less and more developed regions of the world, Table 3. As per these increases, South Africa; Less and More Developed regions; and the world show a capacity to sustain or feed their populations on the strengths of increasing GNI per capita US\$ averages over the 2007 and 2016 period. Even infant mortality rates have declined in these same regions. Nevertheless, Zimbabwe Africa and least developed regions have remained quite depressed in terms of prospective socioeconomic transformation over the 2007-2016 period. Zimbabwe appears to have been socioeconomic cultural decline due to the land reform induced de-industrialization processes for the greater part of the period under scrutiny. If Zimbabwe had a 1940 US\$ GNI per capita in 2007 which declined to 1700US\$ in 2016, what it actually means is that both regionally, continentally and globally Zimbabwe was poorly integrated in the global economy. Further, what it means is that Zimbabwe was literally failing to productively exploit the socioeconomic cultural value availed by the Republic of South Africa, less and more developed nations relatively averaging six (6) to eighteen (18) times going by the GNI per capita averages of Zimbabwe relative that of South Africa and the More Developed regions. 
Analysing the New Millennium Role and Place of Socio-economic Geography in Deepening Regional Economic Cooperation and Integration: The Case of South Africa and Zimbabwe

Table 3. Real and prospective benefits of economic cooperation and integration for South Africa and Zimbabwe within global economy

\begin{tabular}{|c|c|c|c|c|c|c|c|c|c|c|c|}
\hline $\begin{array}{c}\text { Region / } \\
\text { Nation }\end{array}$ & \multicolumn{9}{|c|}{2007} & \multicolumn{4}{|c|}{2016} \\
\hline & $\begin{array}{c}\text { Population } \\
\text { mln [mid } \\
2007]\end{array}$ & $\begin{array}{c}\text { Net } \\
\text { migration } \\
\text { rate per } \\
1000\end{array}$ & $\begin{array}{c}\text { GNI } \\
\text { per } \\
\text { Capita } \\
\text { US\$ }\end{array}$ & $\begin{array}{c}\text { Percent } \\
\text { Urban }\end{array}$ & $\begin{array}{c}\text { Infant } \\
\text { mortality } \\
\text { rate }\end{array}$ & $\begin{array}{c}\text { Population } \\
\text { mln [mid } \\
2016]\end{array}$ & $\begin{array}{c}\text { Net } \\
\text { migration } \\
\text { rate per } \\
1000\end{array}$ & $\begin{array}{c}\text { GNI } \\
\text { per } \\
\text { capita } \\
\text { US\$ }\end{array}$ & $\begin{array}{c}\text { Percent } \\
\text { Urban }\end{array}$ & $\begin{array}{c}\text { Infant } \\
\text { mortality } \\
\text { rate }\end{array}$ \\
\hline World & 6,615 & 0 & 9.940 & 49 & 52 & 7,418 & - & 15.415 & 54 & 36 \\
\hline $\begin{array}{c}\text { More } \\
\text { Developed }\end{array}$ & 1,221 & 3 & 29,680 & 75 & 6 & 1,254 & 3 & 39.963 & 78 & 5 \\
\hline $\begin{array}{c}\text { Less } \\
\text { Developed }\end{array}$ & 4,086 & -0 & 4,760 & 42 & 61 & 6,164 & -0 & 10.214 & 49 & 39 \\
\hline $\begin{array}{c}\text { Least } \\
\text { Developed }\end{array}$ & $\ldots$ & $\ldots$ & $\ldots$ & $\ldots$ & $\ldots$ & 962 & -1 & 2.424 & 41 & 59 \\
\hline Africa & 944 & -0 & 2,550 & 37 & 86 & 1,203 & -1 & 4.802 & 41 & 57 \\
\hline $\begin{array}{c}\text { South } \\
\text { Africa }\end{array}$ & 47.9 & 0 & 11,710 & 53 & 43 & 55.7 & 3 & 12830 & 65 & 34 \\
\hline Zimbabwe & 13.3 & -1 & 1,940 & 36 & 60 & 16 & -3 & 1700 & 33 & 50 \\
\hline
\end{tabular}

Sources: 1) World Population Data Sheet. 2007. Population Reference Bureau. Washington D C.

2) World Population Data Sheet. 2016. Population Reference Bureau. Washington D C.

3) Heywood Andrew. 2011. Global Politics. Palgrave Macmillan. London. p 560.

Equally the inability by Zimbabwe to exploit the socioeconomic cultural value availed by South Africa, Less and More Developed Regions has seen increasing net migration flows with Zimbabwe losing 3 people in every 1000 population, the trends still gains momentum to date rising from -1 to -3 between 2007 and 2016, Table 3 . Even percent urban for Zimbabwe did decline from 36 to 33 over the 2007 and 2016 meaning the process of deindustrialization was gaining momentum. While for Zimbabwe infant mortality rate declined from 60 to 50 $/ 1000$ over the 2007 to 2016 , but it actually remained far higher than the averages for South Africa and the World, Table 3. What it meant in real terms is that Zimbabwe was marginalized and is still not in a good position to exploit the socioeconomic cultural value South Africa, Developed regions and the World offers. With South Africa competitive advantage as high as 12830 US\$ GNI per capita and Zimbabwe at a low 1700 US\$ GNI per capita, it means Zimbabwe on average has a 6.1 times socioeconomic cultural value to derive from the South African economy; while from the Developed regions it has 19,9 times and from the rest of the world 7.7 times socioeconomic cultural value to derive, factors being favourably constant, Table 3 .

Through deepening integration and cooperation with South Africa, Developed regions and the World in general, Zimbabwe could potentially undergo progressive socioeconomic cultural transformation by the same scales it is actually losing it in the contemporary. What it means is that committing to integration with South Africa would mean a nearly 6.1 socioeconomic cultural positive impulse and a closing on the GNI per capita US\$ gap currently so wide at $[12.840$ US $\$-.1 .700$ US $\$=11.140$ US $\$$ ] a huge 11.140US\$. The more Zimbabwe integrates with the Developed regions and the World the greater the possibility of socioeconomic cultural transformation, meaning as integration gains momentum so does industrialization, and the reversal of negative net migration; increasing GNI per capita US\$; increasing percent urban due to industrialization; remarkable declines in infant mortality rate and positivity in many other socioeconomic cultural growth and development variables.

- Role of the North - South and South - South Development Dialogue as a regional integration catalytic variable.

Notwithstanding the presence of historically generated development contradictions within the North - South Development cooperation programs which inherently led to the South - South Dialogue as a parallel institution, opportunities for progressive transformation exist in the same programmes. This contention found expression in a commentary passed on "The Reality of Aid: Special Report on South - South Cooperation 2010: South South Cooperation: A challenge to the aid system?" The overarching commentary was that the report provided development actors with important lessons not just for improving South - South cooperation but also for enhancing the development effectiveness of international development cooperation as a whole. It is essentially this window which socio-economic geography in its theoretical and practical essence attempts to harness in order to fully enhance regional integration as a tool for transformation in South Africa and Zimbabwe within a continental and global setting. Within the North - South Development dialogue, international development programmes are proposed for Africa and its member states. The most recent of these North - South dialogue programmes is the 2000-2015 Millennium Development Goals (MDGs), [14]. The role of socio-economic 
geography in enhancing regional integration by embracing into its fold the MDGs is quite critical and strategic as to speed up transformation in South Africa and Zimbabwe and the rest of sub Saharan Africa. A competent management of productive forces and a rational settlement of population can well reduce and systematically eradicate extreme poverty. Hunger and malnutrition can by great order be reduced through enhancement of regional economic integration in the distribution and planning of industry, agriculture within given socio-economic cultural regions within the nation states under study. Achievement of universal primary education ensures of productive labour and development of human sources critical for sustainable development. Promotion of gender equality and empowerment of women as one of the key Millennium Development Goals gives a leverage to the claim by socio- economic geography on enhancement of regional cooperation in South Africa and Zimbabwe as opportunities to enforce equality in accessing privileges for men and women participating in the process of socio-economic cultural development and transformation of the nation, [18]. The MDG on reduction of child mortality ensures a regeneration of the national economy and population as planning for present and future socio-economic cultural development advances. Rationalization of these processes will require the inputs by socio-economic geography as a science on rationalizing the distribution of productive forces and population settlement. Other key Millennium Development Goals, (MDGs) which enable socio-economic geography to be more relevant in enhancing the transformative role of regional integration are improvement of the health of mothers; combating of HIV / AIDs, malaria, and other diseases; ensure environmental sustainability and the initiation of development of global partnership for development, [14]. The strategic inputs for socio-economic geography in promoting regional integration by way of the MDGs in transforming the industrial centres, capital cities, important towns, other towns, and growth points, development nodes in rural and urban areas as reflected in maps 1-2 and 3 are quite immense. The same opportunities for transformation by way of an appropriate and rational intervention by socio-economic geography in enhancing regional integration are defined in the "2000-2015 Southern African Development Community Regional Indicative Plan, (RISDP)" which is complemented by the Strategic Indicative Plan (SIPO) for the Programme, [14]. The role of socio-economic geography in enhancing regional cooperation will find maximum expression in the realization of the priorities and targets of the RISDP just as with the Millennium Development Goals. These priority areas and targets blend very well with the rational role of socio-economic geography in distribution productive forces and management of productive relations in circumstances of optimizing population settlement patterns. These complementary RISDP goals with their set targets are promotion of trade; economic liberalisation and development; infrastructure support for regional integration, sustainable food security; human and social development. These are complemented further by cross cutting areas as combating of HIV/ AIDs pandemic; promotion of gender equality and development; science and technology; information and communications technology; environment and sustainable development as well as private sector development. Also priorities do exist in politics, defence and security cooperation with special attention accorded preventing; managing and resolving conflict so as to strengthen an sustain national and regional stability, peace and security. In as far as distribution of productive forces and population settlement patterns are concerned the priority areas and targets of the RISDP constitute an opportunity for progressive transformation founded on regional integration, [11], [10]. In other words the socio-economic cultural disparities and territorial socio-economic cultural disparities in both rural and urban areas will gradually get eliminated as the transformation process takes place in the capital cities; industrial centres; important towns; other towns, development nodes and growth points in South Africa and Zimbabwe in the short, medium and long term.

In concluding this sub - question it is critical to note that the priority areas and targets set within the North South and S and South - South - South development cooperation programmes or dialogue are critical in that they better inform the process of rational distribution of productive forces, [7]. This situation enhances regional cooperation as a means for speeding up transformation in the rural and urban areas of the socio-economic cultural regions of South Africa and Zimbabwe in the short, medium and long term.

- Prospects, hurdles and alternatives to role of socio-economic geography in enhancing economic integration.

As shown in the content of the North - South and South - South development cooperation programs priority areas and targets the prospects for enhancing regional integration as a vehicle for transformation are quite abundant. Capital cities; industrial towns; important towns; other towns; development nodes and growth points and development corridors in the rural and urban areas within the socio-economic cultural regions of South Africa and Zimbabwe have greater prospects for transformation; see Maps 1-2 and 3. Nevertheless hurdles emanate from political instability and upheavals which lead to disorganization, disorientation and erosion of all the growth and development potential on which the current processes could have built- on. Alternatives involve 
enabling realization of transformative home grown universally acceptable socio-economic cultural development plans, programmes and strategies to be adopted and implemented in the short, medium and long term. This approach of responding to the constructive and development role of socio-economic geography will by great orders reduce poverty, hunger and disease in South Africa, Zimbabwe and the greater Developing world. Hurdles to enhancement of regional integration emanates from the absence of democratic institutions and the absence of peace and dominance by the bureaucratic elite in the circles of stewardship.

\section{Conclusions and Recommendations} that:

In concluding this paper it would be essential to note

- The role and place of social and economic geography in enhancing regional integration is conceptually perfected and advanced by the introduction of new concepts; terms and terminological phrases to ensure that integration processes are better understood in the process of development and transformation;

- Rational distribution of productive forces in rural and urban areas based on the knowledge and principles of socio-economic geography can lead to reduction of socio-economic cultural disparities as well as territorial socio-economic cultural inequalities, [10];

- North - South as well as South - South development cooperation present socio-economic geography with immense possibilities to enhance transformation based on regional integration. This will essentially manifest in diversification of capital cities; industrial centres; important towns; growth points and development nodes as capital and investments increase, [7];

- $\quad$ Socio-economic geography has immense prospects and alternatives for enhancing regional integration in South Africa and Zimbabwe, as presented by the opportunities availed by the North- South and South - South development cooperation programmes, [11].,[7] and [10]. These offer key result areas and targets which resonate the subject of study of socio-economic geography in a continually changing global context.

- Equally Zimbabwe possesses a great potential for socioeconomic cultural transformation and development by the same scale it is losing socioeconomic cultural value in the contemporary from the Republic of South Africa; the Less and More developed regions and the World in general. Improved economic integration and cooperation with South Africa carries by all scientific logic the panacea for transformation in Zimbabwe within a potentially progressing world.

\section{REFERENCES}

[1] Andre Roux. 2011. Everyone's Guide to the South African Economy. $10^{\text {th }}$ edition. Zebra Press. Cape Town. p 215.

[2] Alaev E B. 1983. Social Economic Geography: Conceptual -Terminological Dictionary. Misle Moscow publishers. Moscow. p 348.

[3] Alioune Sall., ed. 2000. The future competitiveness of African economies. Proceedings of the Dakar Forum, Mar Proceedings of the Dakar Forum, March 1999. Ach 1999. African Features, Karthala, Sankore. Dakar. p 457.

[4] Afrodad. 2003. Africa's external debt: An analysis of African countries external Debt Crisis. Printset. Harare. p 101.

[5] Buthelezi Sipho. 2006. Regional integration in Africa: Prospects and challenges for the $21^{\text {st }}$ century. vol 1 . Ikwezi Africa Publishing. East London. p 237.

[6] Catherine Soanes., Angus Stevenson., eds. 2009. Concise Oxford English Dictionary. $11^{\text {th }}$ edition revised. Oxford University Press. Oxford. p 1681.

[7] Chikowore G. 2017. Transformative essence of Japan Official Development Assistance Policy: Significance for millennium regional economic cooperation and integration in Southern and Sub Saharan Africa 1980-2015 and Post 2015 Agenda Phase. University of Zimbabwe Publications. Harare. p 119.

[8] Chinyamata Chipeta., Klaus Schade. 2007. Deepening integration in SADC. Macroeconomic policies and social impact. A comparative analysis of 10 country studies and surveys of business and non - state actors. Firedrich Ebert Stiftung. Gaborone. p 274.

[9] Frederick P. Stutz., Barney Warf. 2012. The world economy: geography, business, development. International edition. Pearson - Prentice Hall. Glenview. p 435.

[10] Michael Hill. 2009. Rural Settlement and the Urban Impact on the Countryside. Hodder Education. London. p 154.

[11] Nagle Garret. 2005. Development. Access to geography. Atg. Hodder Education. London. p126.

[12] Nafziger Wayne E. 2006. Economic development. $4^{\text {th }}$ edition. Cambridge University Press. Cambridge. p 846.

[13] [13] Stephen Weir. 2011. History's worst decisions and the people who made them. Illustrated edition. Zebra press. Cape Town. p256.

[14] SADC. 2003. Southern African Development Community: Regional Indicative Strategic Development Plan. SADC House. Gaborone. p 147.

[15] SADC. 2005. Official SADC Trade, Industry and Investment Review. SADC $25^{\text {th }}$ Anniversary Commemorative Edition. $9^{\text {th }}$ edition. Southern African 
Marketing Co (Pvt) Ltd + SADC. Gaborone. p 287.

[16] SADC. 1993. Economic Integration in Southern Africa. Vol 1. African Development Bank. Biddles Ltd. Oxford. p 371.

[17] United Nations, DPI. 2004. Basic Facts about the United Nations. October. United Nations. New York. p376.

[18] World Bank. 2003. World Development Indicators.
Worldview-people -environment- economy- states and markets - global links. World Bank. Washington DC. p391.

[19] World Bank. 1997. World Development Report. The state in a changing world. Selected world development indicators. World Bank. Washington DC. p 265.

[20] World Population Data Sheets. Population Reference Bureau. Washington DC. 